\title{
PERANAN GURU AGAMA HINDU DALAM BIMBINGAN KONSELING KEPADA SISWA SEKOLAH DASAR
}

\author{
Oleh: I Gede Dharman Gunawan
IAHN Tampung Penyang Palangka Raya dharman.gunawan@gmail.com

\begin{abstract}
Abstrak
Guru agama Hindu memegang peranan penting dalam pembentukan karakter siswa melalui bimbingan konseling yang optimal. Karenanya kemampuan guru dalam mengatur dan mengendalikan kegiatan belajar mengajar sangat penting. Bahkan sikap guru sering dijadikan pedoman oleh siswa dalam kehidupan sehari-hari. Besarnya pengaruh tersebut mengharuskan guru untuk bersikap dan bertindak hati-hati serta selalu memberikan bimbingan konseling kepada siswa yang menghadapi masalah belajar. Peranan guru Agama Hindu dalam bimbingan konseling kepada siswa sekolah dasar masih perlu ditingkatkan dan lebih dioptimalkan lagi, sehingga siswa mampu menemukan solusi penyelesaian alternatif jika menghadapi masalah belajar. setiap siswa di sekolah dasar memiliki kemampuan belajar maupun masalah belajar yang berbeda-beda. Tentunya guru agama Hindu harus mengetahui karakteristik dari setiap siswa. karena setiap siswa memiliki perbedaan karakter, minat, bakat, motivasi belajar dan masalah belajar.
\end{abstract}

Kata Kunci: Guru Agama Hindu, Bimbingan Konseling, Siswa Sekolah Dasar

I

\section{. PENDAHULUAN}

Mutu pendidikan sering dipersoalkan. Ada yang berpendapat bahwa mutu pendidikan yang ada sekarang ini menurun dan belum memenuhi sebagaimana yang diharapkan, sehingga perlu ditingkatkan. Peningkatan mutu pendidikan tidak mungkin ada tanpa optimalisasi peranan para gurunya. Guru merupakan sumber daya manusia yang sangat menentukan keberhasilan program pendidikan. Guru merupakan unsur manusiawi yang sangat dekat hubungannya dengan anak didik dalam pelaksanaan pendidikan sehari-hari di sekolah dan banyak menentukan keberhasilan anak didik dalam mencapai tujuan pendidikan. Masa anak sekolah dasar adalah masa anak yang merupakan periode penemuan diri menuju suatu pembentukan karakter. Dalam pencapaian karakter yang baik semenjak dini, selain faktor internal yang dimiliki, faktor eksternal juga sangat menentukan, termasuk lingkungan sekitar sekolah dan perlunya peranan guru agama Hindu dalam memberikan bimbingan dan konseling kepada siswa sekolah dasar.

Dalam interaksi belajar mengajar, seorang guru agama Hindu sebagai pengajar akan berusaha secara maksimal dengan menggunakan berbagai keterampilan dan kemampuannya agar anak dapat mencapai tujuan yang diharapkan. Oleh karena itu guru harus dapat menciptakan situasi dimana agar anak dapat belajar sebab sebenarnya 
proses belajar mengajar itu belum dapat dikatakan berakhir kalau anak belum dapat belajar dan belum mengalami masalah belajar dan perubahan tingkah laku, karena perubahan tingkah laku merupakan hasil belajar.

Perubahan tingkah laku dapat diartikan perubahan-perubahan yang mencakup tiga aspek tingkah laku manusia, yaitu aspek afektif, aspek psikomotor dan aspek kognitif. Namun kadang-kadang guru mempunyai anggapan lain dengan menganggap proses belajar mengajar telah berakhir apabila sudah menjelaskan semua materi yang berkaitan dengan bagaimana cara membuat sesuatu. Untuk melaksanakan interaksi belajar mengajar, seorang guru tidak hanya semata-mata membutuhkan kepandaian atau keahlian dibidang materi yang diajarkan saja, artinya tidak semua orang ahli dapat melaksanakan interaksi belajar mengajar dengan baik.

Menurut Amin Ridwan (2017), dalam hasil tulisannya dalam Jurnal Pendidikan yang berjudul "Peran Guru Agama Dalam Bimbingan Konseling Siswa Sekolah Dasar" menyatakan bahwa karakteristik siswa sekolah dasar sangat unik. Perilaku dan model komunikasinya sangat unik karena bawaan sifat kekanak-kanakannya. Guru Sekolah Dasar (SD) yang terdiri dari guru kelas, guru mata pelajaran, merupakan ujung tombak pelaksanaan pendidikan di sekolah dasar. Demi terselenggarannya kegiatan bimbingan di SD, sangat diperlukan peran serta kepala sekolah dan guru Agama serta personil lain yang ada di SD. Jurnal ini membahas definisi peserta didik sekolah dasar serta model bimbingan dan konselingnya.

Guru agama Hindu memegang peranan penting dalam pembentukan karakter anak. Karenanya kemampuan guru dalam mengatur dan mengendalikan kegiatan belajar mengajar sangat penting. Bahkan sikap guru sering dijadikan pedoman oleh peserta didik dalam kehidupan sehari-hari. Besarnya pengaruh tersebut mengharuskan guru untuk bersikap dan bertindak hati-hati serta selalu memberikan bimbingan konseling kepada siswa. Tetapi kenyataan yang ada di masyarakat masih menunjukkan bahwa guru masih belum optimal menyadari sepenuhnya tanggung jawab tersebut. Masih ada orang yang berpendapat bahwa guru belum bisa menciptakan sorga di sekolah, tetapi malah menciptakan neraka dengan membebani siswa dengan berbagai tugas dan wajah galak. Situasi tersebut sedikit banyak akan mempengaruhi prestasi peserta didik.

\section{PEMBAHASAN}

2.1 Pentingnya Bimbingan Konseling kepada Siswa Sekolah Dasar

Pengertian
merupakan suatu $\begin{array}{r}\text { Bimbingan } \\ \text { kegiatan }\end{array}$
pembimbing untuk memberikan
layanan bimbingan dalam hal
membantu orang atau yang
dibimbing menjadi benar. Bimbingan
juga dapat dilakukan kepada siapa
saja dari anak remaja dan dewasa
selama mereka masih memerlukan
bimbingan. Bimbingan dan
konseling adalah merupakan
pertolongan atau bantuan untuk
seseorang yang membutuhkan
bimbingan merupakan pertolongan
yang menuntun. Bimbingan yang


dilakukan adalah untuk membimbing individu supaya mandiri dan berkembang secara optimal. Tetapi dalam hal pertolongan dan bantuan tidak semuanya disebut bimbingan. Seperti orang dapat memberikan pertolongan kepada anak yang jatuh agar bangkit lagi. Konseling merupakan bantuan yang diberikan kepada individu supaya masalah yang dihadapi dapat diselesaikan.

Tujuan Bimbingan dan Konseling Menurut Prayitno (2004), untuk membantu individu dalam menyelesaikan masalah atau membantu peserta didik berkembang secara optimal sesuai dengan keadaan dan tahap perkembangan yang dimilikinya. Dilihat dari aspek berbagai latar belakang seperti latar belakang keluarga, latar belakang pendidikan, status sosial dan ekonomi. Tujuan dari bimbingan dan konseling secara khusus adalah untuk membantu siswa agar dapat mencapai tujuan-tujuan perkembangannya yang terdiri dari aspek pribadi-sosial, belajar (akademik), dan karier.

Peranan Bimbingan

Konseling dalam Pembelajaran Siswa (Salahudin, 2010), antara lain: Bimbingan Belajar yang bertujuan untuk mengatasi masalah-masalah belajar siswa baik di dalam maupun di luar sekolah, antara lain yang di terapkan adalah :

1) Cara belajar efektif secara individu dan kelompok.

2) Cara merencanakan waktu dan kegiatan belajar.

3) Cara mengatasi kesulitan belajar pada mata ajar tertentu.

4) Prosedur yang benar dalam mengikuti pelajaran.

5) Mengatasi masalah pribadi dalam belajar akibat perekonomian, masalah dengan orang tuanya.
6) Cara menganal diri sendiri dan memahami diri dalam mendapatkan kesempatan untuk masa depan maupun sekarang.

Bimbingan Sosial kepada siswa sekolah dasar bertujuan membantu dan mengatasi kesulitankesulitan dalam masalah sosial, sehingga dapat menyesuaikan diri dengan kelompok lain dan tercipta pembelajaran yang kondusif. Bimbingan tersebut yang maksutkan untuk :

1) Dapat bermain dan belajar yang sesuai dengan kelompok lain

2) Mendapatkan persahabatan yang sesuai.

3) Mendapatkan kelompok yang dapat memecahakan masalah tertentu.

Bimbingan mengatasi masalah pribadi individu yang belum teratasi dan mengganggu konsentrasi dan proses belajar, akibatnya prestasi yang dicapai rendah atau di bawah rata-rata. Layanan bimbingan kepada siswa di sekolah dasar pun bermanfaat antara lain untuk :

1) Menstimulasi peserta didik dalam meningkatkan partisipasinya dalam kegiatan belajar mengajar.

2) Menciptakan pengalaman belajar yang penuh arti.

3) Meningkatkan motivasi belajar.

4) Meningkatkan kemauan dalam minat balajar.

5) Menciptakan suasana yang menyenangkan dengan kelompok lain.

Layanan Bimbingan

Konseling kepada siswa Dari layanan bimbingan konseling di sekolah yang diberikan untuk meningkatkan atau membantu dalam beberapa aspek (Prayitno, 2004) yaitu :

a. Pengembangan pribadi, yaitu membantu dalam memahami serta 
menilai bakat, minat dan pola fikir remaja menuju kedewasaan.

b. Pengembangan kehidupan sosial, yaitu bimbingan yang membantu dalam memahami dan menilai serta mengembangkan kemampuan bersosialisasi dengan baik, harmoni, dinamis dan bermartabat dalam lingkungannya.

c. Pengembangan kemampuan belajar, yaitu membantu peserta didik untuk meningkatkan kemampuan belajar secara mandiri dalam mengikuti pendidikan sekolah sehingga dapat mengikuti pelajaran dengan afektif.

d. Pengembangan karier, yaitu membantu dalam hal memahami dan menilai informasi sehingga dapat mengabil keputusan berkarier.

\subsection{Peranan Guru Agama Hindu Dalam Bimbingan Konseling Kepada Siswa Sekolah Dasar}

Peran guru agama Hindu dalam bimbingan konseling kepada di sekolah dasar, tugas dan tanggung jawab utama guru adalah melaksanakan kegiatan pembelajaran siswa. Kendati demikian, bukan berarti dia sama sekali lepas dengan kegiatan pelayanan bimbingan dan konseling. Peran dan konstribusi guru mata pelajaran terkhususnya mata pelajaran pendidikan agama Hindu tetap sangat diharapkan guna kepentingan efektivitas dan efisien pelayanan Bimbingan dan Konseling di sekolah. Bahkan dalam batas-batas tertentu guru pun dapat bertindak sebagai konselor bagi siswanya. Wina Senjaya (2006) menyebutkan salah satu peran yang dijalankan oleh guru yaitu sebagai pembimbing dan untuk menjadi pembimbing baik guru harus memiliki pemahaman tentang anak yang sedang dibimbingnya. Sementara itu, berkenaan peran guru mata pelajaran dalam bimbingan dan konseling, Guru-guru mata pelajaran dalam melakukan pendekatan kepada siswa harus manusiawi-religius, bersahabat, ramah, mendorong, konkret, jujur dan asli, memahami dan menghargai tanpa syarat. Prayitno (2004) memerinci peran, tugas dan tanggung jawab dalam bimbingan dan konseling adalah :

1. Membantu memasyarakatkan pelayanan bimbingan dan konseling kepada siswa

2. Membantu guru pembimbing/konselor mengidentifikasi siswa-siswa yang memerlukan layanan bimbingan dan konseling, serta pengumpulan data tentang siswa-siswa tersebut.

3. Mengalih tangankan siswa yang memerlukan pelayanan bimbingan dan konseling kepada guru pembimbing/konselor

4. Menerima siswa alih tangan dari guru pembimbing/konselor, yaitu siswa yang menuntut guru pembimbing/konselor

memerlukan pelayanan pengajar /latihan khusus (seperti pengajaran/ latihan perbaikan, program pengayaan).

5. Membantu mengembangkan suasana kelas, hubungan guru-siswa dan hubungan siswa-siswa yang menunjang pelaksanaan pelayanan pembimbingan dan konseling.

6. Memberikan kesempatan dan kemudahan kepada siswa 


$\begin{array}{lr}\text { yang } & \text { memerlukan } \\ \text { layanan/kegiatan } & \text { bimbingan } \\ \text { dan konseling } & \text { untuk } \\ \text { mengikuti } & \text { /menjalani } \\ \text { layanan/kegiatan } & \text { yang } \\ \text { dimaksudkan itu. } & \end{array}$

7. Berpartisipasi dalam kegiatan khusus penanganan masalah siswa, seperti konferensi kasus.

8. Membantu pengumpulan informasi yang diperlukan dalam rangka penilaian pelayanan bimbingan dan konseling serta upaya tindak lanjutnya.

Implementasi kegiatan bimbingan konseling dalam pelaksanaan Kurikulum Berbasis Kompetensi sangat menentukan keberhasilan proses belajarmengajar. Oleh karena itu peranan guru agama Hindu dalam pelaksanaan kegiatan bimbingan konseling sangat penting dalam rangka mengefektifkan pencapaian tujuan pembelajaran yang dirumuskan.

Sardiman

menyatakan bahwa ada sembilan peran guru dalam kegiatan Bimbingan Konseling, yaitu:

1. Informator, guru diharapkan sebagai pelaksana cara mengajar informatif, laboratorium, studi lapangan, dan sumber informasi kegiatan akademik maupun umum.

2. Organisator, guru sebagai pengelola kegiatan akademik, silabus, jadwal pelajaran dan lain-lain.

3. Motivator, guru harus mampu merangsang dan memberikan dorongan serta reinforcement untuk mendinamisasikan potensi siswa, menumbuhkan swadaya (aktivitas) dan daya cipta (kreativitas) sehingga akan terjadi dinamika di dalam proses belajarmengajar.

4. Director, guru harus dapat membimbing dan mengarahkan kegiatan belajar siswa sesuai dengan tujuan yang dicita-citakan.

5. Inisiator, guru sebagai pencetus ide dalam proses belajar-mengajar.

6. Transmitter, guru bertindak selaku penyebar kebijaksanaan dalam pendidikan dan pengetahuan.

7. Fasilitator, guru akan memberikan fasilitas atau kemudahan dalam proses belajar-mengajar.

8. Mediator, guru sebagai penengah dalam kegiatan belajar siswa.

9. Evaluator, guru mempunyai otoritas untuk menilai prestasi anak didik dalam bidang akademik maupun tingkah laku sosialnya, sehingga dapat menentukan bagaimana anak didiknya berhasil atau tidak.

Lebih jauh, dikemukakan pula tentang peranan guru yang berhubungan dengan aktivitas pengajaran dan administrasi pendidikan, diri pribadi, dan dari sudut pandang psikologis. Dalam hubungannya dengan aktivitas pembelajaran dan administrasi pendidikan, guru berperan sebagai :

1. Pengambil inisiatif, pengarah, dan penilai pendidikan;

2. Wakil masyarakat di sekolah, artinya guru berperan sebagai pembawa suara dan kepentingan masyarakat dalam pendidikan; 
3. Seorang pakar dalam bidangnya, yaitu menguasai bahan yang harus diajarkannya;

4. Penegak disiplin, yaitu guru harus menjaga agar para peserta didik melaksanakan disiplin;

5. Pelaksana administrasi pendidikan, yaitu guru bertanggung jawab agar pendidikan dapat berlangsung dengan baik;

6. Pemimpin generasi muda, artinya guru bertanggung jawab untuk mengarahkan perkembangan peserta didik sebagai generasi muda yang akan menjadi pewaris masa depan; dan

7. Penterjemah masyarakat, yaitu guru berperan untuk menyampaikan berbagai kemajuan ilmu pengetahuan dan teknologi kepada masyarakat.

Di pandang dari segi diripribadinya (self oriented), seorang guru berperan sebagai :

1. Pekerja sosial (social worker), yaitu seorang yang harus memberikan pelayanan kepada masyarakat;

2. Pelajar dan ilmuwan, yaitu seorang yang harus senantiasa belajar secara terus menerus untuk mengembangkan penguasaan keilmuannya;

3. Orang tua, artinya guru adalah wakil orang tua peserta didik bagi setiap peserta didik di sekolah;

4. model keteladanan, artinya guru adalah model perilaku yang harus dicontoh oleh mpara peserta didik; dan
5. Pemberi keselamatan bagi setiap peserta didik. Peserta didik diharapkan akan merasa aman berada dalam didikan gurunya.

Sementara itu, Doyle sebagaimana dikutip oleh Danim (2002) mengemukan dua peran utama guru dalam pembelajaran yaitu menciptakan keteraturan (establishing order) dan memfasilitasi proses belajar (facilitating learning). Yang dimaksud keteraturan di sini mencakup hal-hal yang terkait langsung atau tidak langsung dengan proses pembelajaran, seperti : tata letak tempat duduk, disiplin peserta didik di kelas, interaksi peserta didik dengan sesamanya, interaksi peserta didik dengan guru, jam masuk dan keluar untuk setiap sesi mata pelajaran, pengelolaan sumber belajar, pengelolaan bahan belajar, prosedur dan sistem yang mendukung proses pembelajaran, lingkungan belajar, dan lain-lain.

Sejalan dengan tantangan kehidupan global, peran dan tanggung jawab guru pada masa mendatang akan semakin kompleks, sehingga menuntut guru untuk senantiasa melakukan berbagai peningkatan dan penyesuaian kemampuan profesionalnya. Guru harus lebih dinamis dan kreatif dalam mengembangkan proses pembelajaran peserta didik. Guru di masa mendatang tidak lagi menjadi satu-satunya orang yang paling well informed terhadap berbagai informasi dan pengetahuan yang sedang tumbuh, berkembang, berinteraksi dengan manusia di jaman milenial ini. Di masa depan, guru bukan satu-satunya orang yang lebih pandai di tengah-tengah peserta didiknya. 
Jika guru tidak memahami

mekanisme dan pola penyebaran informasi yang demikian cepat, ia akan terpuruk secara profesional. Kalau hal ini terjadi, ia akan kehilangan kepercayaan baik dari peserta didik, orang tua maupun masyarakat. Untuk menghadapi tantangan profesionalitas tersebut, guru perlu berfikir secara antisipatif dan proaktif. Artinya, guru harus melakukan pembaruan ilmu dan pengetahuan yang dimilikinya secara terus menerus. Disamping itu, guru masa depan harus paham penelitian guna mendukung terhadap efektivitas pengajaran yang dilaksanakannya, sehingga dengan dukungan hasil penelitiaan guru tidak terjebak pada praktek pengajaran yang menurut asumsi mereka sudah efektif, namum kenyataannya justru mematikan kreativitas para peserta didiknya. Begitu juga, dengan dukungan hasil penelitian yang mutakhir memungkinkan guru untuk melakukan pengajaran yang bervariasi dari tahun ke tahun, disesuaikan dengan konteks perkembangan ilmu pengetahuan dan teknologi yang sedang berlangsung.

\section{SIMPULAN}

Peran guru agama Hindu dalam bimbingan konseling di sekolah, tugas dan tanggung jawab utama guru adalah melaksanakan kegiatan pembelajaran siswa. Kendati demikian, bukan berarti dia sama sekali lepas dengan kegiatan pelayanan bimbingan dan konseling. Peran dan konstribusi guru mata pelajaran tetap sangat diharapkan guna kepentingan efektivitas dan efisien pelayanan Bimbingan dan Konseling di sekolah. Bahkan dalam batas-batas tertentu guru pun dapat bertindak sebagai konselor bagi siswanya. Peranan guru agama Hindu dalam memberikan bimbingan konseling kepada siswa sekolah dasar masih perlu ditingkatkan dan lebih dioptimalkan lagi, sehingga siswa dapat menyelesaikan berbagai masalah belajar yang mereka hadapi. Tentunya siswa diharapkan mampu menemukan solusi penyelesaian alternatif jika menghadapi masalah belajar. Faktor yang dapat mempengaruhi peranan Guru Agama Hindu dalam dalam bimbingan konseling kepada siswa sekolah dasar bahwa, setiap siswa memiliki kemampuan belajar yang berbedabeda maupun masalah belajar yang berbeda-beda. Tentunya guru agama Hindu harus mengetahui karakteristik dari setiap siswa. karena setiap siswa memiliki perbedaan karakter, minat, bakat, motivasi belajar dan masalah belajar yang berbeda.

\section{Daftar Pustaka}

Danim, Sudarwan. 2002. Inovasi Pendidikan dalam Upaya Peningkatan

Profesionalisme Tenaga kependidikan. Bandung : Pustaka Setia.

Djamarah, Saiful Bahri. 2002. Psikologi Belajar. Jakarta: PT. Rineka Cipta.

Ridwan, Amin. 2017. Peran Guru Agama Dalam Bimbingan Konseling Siswa Sekolah Dasar. Jurnal Pendidikan.

Salahudin, Anas. 2010. Bimbingan dan Konseling. Bandung: Pustaka Setia.

Sardiman, A.M. 2001. Interaksi dan Motivasi Belajar Mengajar. Jakarta : Raja Grafindo Persada. 
Prayitno, dkk. 2004. Pedoman Khusus Bimbingan dan Konseling. Jakarta : Depdiknas.

Wina, Senjaya. 2006. Strategi Pembelajaran; Berorientasi Standar Proses Pendidikan. Jakarta: Kencana Prenada Media Group 